\title{
Upaya Menciptakan Budaya Anti Korupsi Melalui Tradisi Banjar
}

\author{
Novitasari ${ }^{1}$ \\ bbqenak@untidar.ac.id
}

\begin{abstract}
Abstrak
Pencegahan korupsi belum banyak dilakukan melalui kearifan lokal, misalnya melalui tradisi Banjar. Oleh karena itu, tujuan penelitian ini adalah untuk mengungkap upaya pembangunan budaya anti korupsi pada masyarakat melalui pelaksanaan Banjar. Penelitian ini menggunakan pendekatan kualitatif dengan metode studi kasus. Data diperoleh melalui wawancara dan studi literatur. Teknik analisis data menggunakan model Miles and Huberman. Hasil penelitian menunjukkan bahwa pelaksanaan Banjar khususnya dalam begawe merariq dapat menjadi upaya masyarakat dalam membudayakan nilai-nilai anti korupsi. Perilaku anggota Banjar dalam melaksanakan begawe merariq membudayakan penerapan nilai-nilai anti korupsi, antara lain jujur, disiplin, tanggung jawab, kerja keras, sederhana, mandiri, adil, berani, dan peduli. Saran-saran yang dapat penulis berikan berdasarkan hasil penelitian ini, yaitu: 1) Masyarakat Indonesia kaya dengan kearifan lokal yang mengandung nilai-nilai positif termasuk pelaksanaan banjar ini sehingga harus dilestarikan; 2) pembudayaan nilai anti korupsi melalui pelaksanaan Banjar merupakan sebuah pengalaman yang dapat menjadi referensi dalam pembelajaran pada pendidikan formal di sekolah maupun di perguruan tinggi sehingga memiliki manfaat yang berkelanjutan.
\end{abstract}

Kata Kunci: Banjar, Kearifan Lokal, Lombok, Nilai Anti Korupsi, Tradisi

\begin{abstract}
Prevention of corruption has not been done much through local wisdom, for example through the tradition of Banjar. Therefore, the purpose of this study is to reveal the efforts to develop an anti-corruption culture in the community through the implementation of the Banjar. This study used a qualitative approach with a case study method. Data was obtained through interviews and literature studies. The data analysis technique used the Miles and Huberman model. The result of the study shows that the implementation of the Banjar especially in begawe merariq can be an effort of the community to cultivate anti-corruption values. The behavior of the members of the banjar in carrying out begawe merariq cultivates the application of anticorruption values, including honesty, discipline, responsibility, hard work, simple, independent, fair, courageous, and caring. The suggestions that the author can give are based on the results of this study, namely: 1) Indonesian society is rich in local wisdom that contains positive values including the implementation of this banjar so it must be preserved; 2) civilizing the value of anti-corruption through the implementation of Banjar is an experience that can be a reference in learning in formal education in schools and in universities so that it has sustainable benefits.
\end{abstract}

Keywords: Anti-Corruption Value, Banjar, Culture, Local Wisdom, Lombok.

\section{Pendahuluan}

Korupsi merupakan sebuah tindak pidana yang dapat menghancurkan sebuah organisasi termasuk negara. Sedangkan di Indonesia, korupsi semakin marak

\footnotetext{
${ }^{1}$ Korespondensi: Prodi Ilmu Administrasi Negara Universitas Tidar. Jl. Kapten Suparman No. 39, Magelang. Telp. (0293) 362438
} 
terjadi hingga menjadikan Indonesia sebagai salah satu negara dengan tingkat korupsi yang tinggi di dunia. Budiawati (2018) melaporkan bahwa Transparency International merilis Indeks Persepsi Korupsi (IPK) 2017 dan menunjukkan bahwa Indonesia menduduki peringkat ke-96 dari 180 negara di dunia yang paling bersih dari korupsi. Apabila peringkat tersebut dibaca terbalik maka Indonesia berada di peringkat ke-84 sebagai negara terkorup di dunia. Dengan demikian, tidak menutup kemungkinan korupsi dapat mengantarkan Indonesia menjadi negara gagal apabila tidak segera ditangani dengan maksimal.

Pemerintah telah mengupayakan untuk memberantas tindak pidana korupsi dengan mendirikan Komisi Pemberantasan Korupsi (KPK). Akan tetapi, korupsi masih marak terjadi sehingga dikhawatirkan kelak korupsi dianggap sebagai hal biasa dan lumrah. Oleh karena itu, pencegahan dan pemberantasan korupsi memerlukan upaya semua pihak baik pemerintah, pejabat, penyelenggara pendidikan, maupun masyarakat sipil. Pencegahan korupsi dalam masyarakat dapat dilakukan melalui penguatan kearfian lokal.

Nurinten, dkk. (2016) mengatakan bahwa pencegahan korupsi dapat dilakukan dengan menanamkan karakter anti korupsi melalui penguatan kearifan lokal yang salah satunya adalah dongeng jeung kaulinan keur barudak (dongeng dan permainan untuk anak-anak). Dongeng tersebut merupakan kearifan lokal suku Sunda sehingga berbasis pada budaya Sunda yang menekankan pada lima nilai, yaitu: kejujuran, disiplin, kerja keras, tanggung jawab, dan rendah hati. Subjek penelitian pada penelitian Nurinten, dkk tersebut adalah anak usia dini dan hasilnya menunjukkan bahwa kelas PAUD (Pendidikan Anak Usia Dini) yang menggunakan strategi dongkrak memiliki pemahaman yang signifikan tentang karakter antikorupsi. Rusdi dan Prasetyaningrum (2016) menuliskan pada pembahasan penelitiannya bahwa semakin menguat internalisasi budaya masyarakat maka dapat menjadi salah satu faktor untuk menekan terjadinya perilaku korupsi karena budaya sirina pace mengandung nilai-nilai, antara lain: aktualisasi diri, rasa malu dan rasa bersalah, kesetiaan, dan kejujuran. Rahmatiani (2016) mengemukakan bahwa penguatan tradisi budaya lokal khususnya tradisi Sunda dapat menjadi bekal untuk menghadai tantangan pembangunan daerah karena tradisi tersebut mempunyai pesan bahwa agar setiap manusia bermanfaat bagi kehidupan semua orang. Rizal dan Farid (2017) menjelaskan dalam penelitiannya bahwa 
konkritisasi pitutur lubur secara tidak langsung mempunyai pengaruh pencegahan terhadap praktik korupsi sehingga konkritisasi dapat melalui pendidikan, seni dan budaya, serta kegiatan lain yang melibatkan masyarakat. Rizal dan Farid (2017) menambahkan bahwa mentransformasikan nilai, pemikiran atau ajaran yang ada dalam kearifan lokal untuk ditarik ke masa kini bukan hal yang mudah karena kearifan lokal menjadi diskursus. Santoso dan Meyrasyawati (2015) mengemukakan dalam penelitiannya bahwa korupsi yang dilakukan semakin massif dan berjamaah mengindikasikan ada sikap mental dalam tradisi masyarakat yang memberikan peluang terjadinya korupsi. Santoso dan Meyrasyawati (2015) menambahkan bahwa korupsi harus diletakkan pada konteks kebudayaan selain merupakan peristiwa hukum sehingga pencegahan dan pemberantasannya juga melalui pendekatan hukum dan pendekatan kebudayaan.

Berdasarkan data dari beberapa penelitian terdahulu tersebut maka dapat dipahami bahwa pencegahan dan pemberantasan korupsi tidak dapat hanya dilakukan melalui pendekatan hukum tetapi juga pendekatan kebudayaan. Akan tetapi, tidak semua budaya mengandung nilai-nilai anti korupsi sehingga penguatan kearifan lokal hanya menjadi alternatif untuk mencegah dan memberantas korupsi. Oleh karena itu, penelitian ini memfokuskan pada upaya menciptakan budaya anti korupsi melalui tradisi banjar. Penelitian ini akan mengungkap bagaimana pelaksanaan tradisi banjar sehingga dapat menciptakan budaya anti korupsi pada masyarakat.

\section{Tinjauan Pustaka}

\section{Praktik Korupsi di Berbagai Daerah}

Santoso dan Meyrasyawati (2015) mengemukakan bahwa terdapat tiga tahapan perkembangan korupsi di Indonesia, antara lain: elitis, endemik, dan sistemik. Tahap elitis berarti bahwa korupsi menjadi patologi sosial yang khas di kalangan kaum elit atau pejabat. Tahap endemik yaitu wabah korupsi yang diawali dari kalangan orangorang berpengaruh kemudian menjangkau hingga ke seluruh lapisan masyarakat. Tahap sistemik terjadi ketika korupsi dilakukan oleh setiap individu dalam system. Utari menjelaskan bahwa dalam masyarakat yang memiliki sistem budaya dan lembaga yang korup maka akan membentuk individu yang korup meski sebesar apapun 
kesalehan individu (Fauziyah, 2015). Oleh karena itu, praktik-praktik korupsi masih terjadi di Indonesia.

Menurut data Indonesia Corruption Watch (ICW), terdapat lima provinsi dengan jumlah kasus korupsi tertinggi pada tahun 2017, antara lain: 68 kasus korupsi di Jawa Timur, 42 kasus korupsi di Jawa Barat, 40 kasus korupsi di Sumatera Utara, 29 kasus korupsi di Aceh, dan 29 kasus korupsi di Jawa Tengah. Dari kelima provinsi tersebut, Jawa Barat menjadi provinsi dengan jumlah nilai kerugian yang paling besar bagi Negara, yaitu Rp 647 miliar. Satu kasus korupsi di Jawa Barat yang memiliki nilai kerugian terbesar adalah kasus dugaan korupsi pencairan kredit fiktif di Bank Jabar (BJB) Syariah yang menimbulkan kerugian bagi Negara sekitar Rp 628 miliar dan diproses oleh Bareskrim Polri (Antikorupsi.org, 2017). Berdasarkan data tersebut, terdapat sepuluh actor yang ditetapkan sebagai tersangka kasus korupsi, yaitu: 495 tersangka dari ASN (Aperatur Sipil Negara), 241 tersangka dari swasta, 102 tersangka merupakan kepala desa, 59 tersangka dari masyarakat, 50 tersangka dari dirut/karyawan BUMN, 44 tersangka dari ketua/anggota organisasi, 38 tersangka dari aparatus desa, 37 tersangka merupakan ketua/anggota DPRD, 30 tersangka dari kepala daerah, dan 30 tersangka dari dirut/karyawan BUMD. Sementara pengelompokan kasus korupsi berdasarkan kaitannya dengan korupsi dana desa dan kepala daerah pada tahun 2017 diperoleh data yang menunjukkan bahwa terdapat lima sektor dengan kasus korupsi terbanyak sepanjang tahun 2017, antara lain: sektor anggaranm desa, pemerintahan, pendidikan, transportasi, dan sosial kemasyarakat. Menurut ICW, terdapat 98 kasus korupsi pada sektor anggaran desa, 56 kasus pada sektor pemerintahan, 53 kasus pada sektor pendidikan, 52 kasus pada sektor transportasi, dan 40 kasus pada sektor sosial kemasyarakat.

Kasus-kasus korupsi yang terjadi di berbagai daerah tersebut dapat terjadi karena berbagai hal. Menurut World Bank (Setiyono, 2017) menjelaskan bahwa ada dua persoalan pokok yang dapat menyebabkan terjadinya korupsi, yaitu: motivasi personal dan sistem yang buruk. Dari segi personal individu, korupsi dapat terjadi karena memiliki motivasi untuk memperoleh keuntungan yang lebih, misalnya melakukan penggelapan uang Negara dengan melakukan suap sehingga dapat membayar pajak yang lebih rendah bahkan menunggak. Keinginan individu untuk memperoleh promosi jabatan, memenangkan lelang, atau memperoleh keuntungan yang lain dengan cara 
memberikan uang pelicin. Salah satu kasus akibat suap yaitu kasus korupsi yang terjadi di Jawa Timur. Pada tahun 2017, KPK melakukan Operasi Tangkap Tangan (OT'T) di Pamekasan yang kemudian menetapkan lima orang tersangka termasuk Bupati Pamekasan Achmad Syafii dan kepala desa Dassok Agus Mulyadi. Pada kasus tersebut, Kepala Kejaksaan Negeri Pamekasan Rudi Indra Prasetya diduga menerima suap untuk menutup kasus korupsi penyelewengan dana desa (Gabrillin, 2018).

Penyebab korupsi selanjutnya adalah sistem yang buruk. Setiyono (2017) mengemukakan bahwa sistem yang buruk yang menyebabkan terjadinya korupsi pada level daerah karena beberapa persoalan, yaitu: adanya kesempatan, rendahnya resiko untuk tertangkap, insentif kerja yang buruk, dan sikap atau keadaan yang mengabaikan hukum. Salah satu contoh terjadinya korupsi akibat sistem yang buruk yaitu adanya pungutan liar yang dilakukan oleh oknum pejabat pada pemerintah daerah. Ketua Satuan Tugas Sapu Bersih Pungutan Liar (Saber Pungli mengungkapkan bahwa pada tahun 2017 telah dilakukan OT'T sebanyak 1.201 terhadap tindakan pungutan liar yang kemudian menetapkan 2.426 tersangka dengan barang bukti uang hingga Rp 315,6 miliar. Temuan barang bukti OTT paling tinggi terjadi di Kalimantan Timur yaitu sebesar Rp 298 miliar, sedangkan paling rendah di Papua Barat yaitu sebesar Rp 400 ribu (nasional.tempo.co, 2017). Dengan demikian, kasus korupsi masih marak terjadi khususnya di daerah, meskipun tindakan pencegahan dan pemberantasan telah dilakukan oleh lembaga-lembaga formal.

\section{Strategi Pencegahan Korupsi melalui Penguatan Kearifan Lokal}

Pencegahan terhadap terjadinya tindakan korupsi tidak dapat dilakukan hanya oleh lembaga-lembaga formal yang memiliki kewenangan tetapi juga harus melibatkan masyarakat karena korupsi bukan hanya dilakukan oleh individu melainkan sistemik. Santoso dan Meyrasyawati (2015) mengemukakan bahwa terdapat tren baru dalam perilaku korupsi dimana korupsi tidak lagi dilakukan secara personal tetapi secara komunal karena kejahatan akan lebih aman apabila dilakukan secara bersama atau disebut dengan istilah perilaku banalitas korupsi. Santoso dan Meyrasyawati (2015) menambahkan bahwa pencegahan korupsi dapat dilakukan dengan melakukan mekanisme control terhadap penyelenggaraan pemerintahan dan internalisasi 
pendidikan anti korupsi kepada masyarakat melalui pendidikan di sekolah maupun internalisasi langsung dalam kehidupan masyarakat.

Nilai-nilai anti korupsi meliputi sembilan nilai, antara lain: jujur, disiplin, tanggung jawab, kerja keras, sederhana, mandiri, adil, berani, dan peduli. Bura dan Puspito (Fauziyah, 2015) mengemukakan bahwa kejujuran adalah perilaku yang didasarkan pada upaya menjadikan dirinya sebagai orang yang selalu dapat dipercaya dalam perkataan, tindakan dan pekerjaan. Menurut Bura dan Puspito (Fauziyah, 2015), tanggung jawab merupakan perilaku dan sikap yang melaksanakan tugas dan kewajiban yang harus dilakukan terhadap diri sendiri, masyarakat, lingkungan (alam, sosial, dan budaya), negara dan Tuhan.

Kerja keras menurut Bura dan Puspito (Fauziyah, 2015), didefinisikan sebagai perilaku yang menunjukkan upaya sungguh-sungguh dalam mengatasi berbagai hambatan, belajar, dan tugas, serta menyelesaikan tiga dengan sebaik-baiknya. Sederhana menurut Bura dan Puspito (Fauziyah, 2015) diartikan sebagai perilaku yang tidak berlebihan, apa adanya, hemat, rendah hati, dan sesuai kebutuhan. Mandiri menurut Bura dan Puspito (Fauziyah, 2015) didefinisikan sebagai perilaku dan sikap yang tidak mudah bergantung pada orang lain dan masyarakat yang membutuhkan. Adil menurut Bura dan Puspito (Fauziyah, 2015) didefinisikan sebagai perilaku dan sikap yang tidak berat sebelah, tidak memihak, tidak pilih kasih, berpihak pada kebenaran, sepatutnya, seimbang, obyektif, dan proporsional. Kepedulian menurut Boyatzis \& McKee (Prayitno, 2016) adalah wujud dari empati dan perhatian yang mendorong manusia untuk menjalin hubungan dengan orang lain. Kesembilan nilai anti korupsi tersebut perlu dibudayakan dalam masyarakat untuk mencegah terjadinya korupsi.

Santoso dan Meyrasyawati (2015) mengemukakan bahwa pemberantasan dan pencegahan korupsi tidak dapat hanya dilakukan melalui pendekatan hukum tetapi juga melalui pendekatan kebudayaan. Wirawan (Santoso dan Meyrasyawati, 2015) mengatakan bahwa korupsi yang sudah menyerang sistem sehingga melembaga dan membudaya maka dilawan dengan menumbuhkan budaya anti korupsi. Penumbuhan budaya anti korupsi yang memuat perilaku warga masyarakat sesuai dengan nilai-nilai anti korupsi memerlukan strategi kebudayaan yang terdiri atas:1) pembiasaan dan penciptaan; 2) internalisasi pendidikan; 3) komitmen bersama dalam ikatan kelompok. 
Dengan demikian, strategi kebudayaan dapat berupa penguatan kearifan lokal masyarakat.

\section{Model Pencegahan Korupsi melalui Tradisi Banjar}

Budaya merupakan hasil dari proses rasa, karsa, dan cipta manusia untuk meningkatkan harkat dan martabat manusia (Kristanto, 2015). Saptono (Saifulloh, 2017) mengemukakan bahwa pencegahan korupsi dapat dilakukan melalui perbaikan sistem hukum, kelembagaan, dan budaya masyarakat. Budaya anti korupsi dalam masyarakat dapat tumbuh dan berkembang apabila masyarakat memiliki kemauan dan kebiasaan untu mewujudkan nilai-nilai anti korupsi dalam kehidupan sehari-hari (Nasih, dalam Saifulloh, 2017).

Model pencegahan korupsi dapat dilakukan dengan penguatan kearifan lokal. Kearifan lokal yang ada dalam masyarakat yang mengadung nilai-nilai anti korupsi dilestarikan dan diwariskan kepada generasi selanjutnya. Apabila nilai-nilai anti korupsi telah dihayati oleh masyarakat maka akan tercegah dari terjadinya tindakan korupsi. korupsi terjadi bukan hanya karena keinginan individu untuk memperkaya diri sendiri melainkan oleh faktor lain. Santoso (2015) mengatakan bahwa korupsi terjadi karena menguatnya kecenderungan habituasi korupsi dan kendala dalam budaya yang berdampak pada lemahnya upaya pemberantasan korupsi. Dengan demikian, strategi pendekatan kebudayaan dapat menjadi model pencegahan terjadinya korupsi dalam masyarakat, salah satunya tradisi Banjar yang ada dalam masyarakat suku Sasak, Lombok, Nusa Tenggara Barat.

\section{Metode Penelitian}

Marzuki mengemukakan bahwa terdapat beberapa pendekatan yang menurutnya lazim digunakan untuk memecahkan suatu permasalahan hukum dalam sebuah penelitian hukum, yaitu statue approach, case approach, historical approach, comparative approach, dan conseptual approach (Rahmatulloh 2017). Akan tetapi, penelitian ini bukan merupakan sebuah penelitian hukum meskipun terkait dengan pecegahan dan pemberantasan korupsi. Peneliti menggunakan pendekatan penelitian kualitatif.

Penelitian kualitatif memiliki beberapa ciri-ciri khusus, antara lain: (1) berusaha mengeksplorasi permasalahan untuk mengembangkan pemahaman secara 
mendetail tentang fokus kajian; (2) tinjauan pustaka tidak memiliki peran sentral dalam penelitian, tetapi digunakan untuk menjustifikasi permasalahan sehingga tinjauan pustaka dapat berkembang sesuai dengan kebutuhan penelitian; (3) maksud dan pertanyaan penelitian disajikan dalam bentuk terbuka untuk menangkap pengalaman partisipan; (4) pengumpulan data berdasarkan pada kata-kata dan gambar dari sejumlah kecil individu sehingga diperoleh pandangan partisipan; (5) analisis data menggunakan analisis teks dan interpretasi makna dari temuan penelitian; (6) laporan yang ditulis bersifat fleksibel dan evaluatif serta memasukkan refleksi dan bias subjektif peneliti (Creswell, 2015). Peneliti berusaha mengungkap deskripsi tentang pelaksanaan banjar yang dapat menjadi upaya dalam penanaman nilai anti korupsi pada masyarakat sehingga menggunakan pendekatan penelitian kualitatif.

Metode penelitian yang digunakan dalam penelitian ini adalah studi kasus. Metode studi kasus adalah serangkaian kegiatan penelitian yang dilakukan dengan menggali secara mendalam tentang suatu program, peristiwa, dan aktivitas yang terkait dengan perorangan, sekelompok orang, lembaga, atau organisasi sehingga memperoleh informasi yang dapat dipelajari atau ditarik dari kasus tersebut (Rahardjo, 2017). Penelitian ini memfokuskan pada satu fenomena yang unik yaitu pelaksanaan banjar pada masyarakat desa Penajak, kecamatan Praya, kabupaten Lombok Tengah.

Pengumpulan data melalui kegiatan wawancara, dan studi literatur. Peneliti bertindak sebagai buman instrument. Menurut Sugiyono (Alhamid dan Anufia, 2019) mengatakan bahwa peneliti sebagai buman instrument karena peneliti menetapkan focus penelitian, memilih sumber data, melakukan analisis data dan menafsirkan serta membuat kesimpulan atas hasil temuan penelitian. Peneliti melakukan wawancara dengan partisipan yang terkait dengan penelitian. Pemilihan partisipan sebagai subjek penelitian menggunakan teknik snowball sampling. Snowball sampling adalah pengambilan sampel penelitian dengan meminta partisipan untuk mengidentifikasi orang lain yang sekiranya dapat memberikan data yang dibutuhkan dalam penelitian (Creswell, 2015).

\section{Hasil dan Pembahasan}

\section{Pelaksanaan Tradisi Banjar di Kampung Kakong}

Banjar adalah salah satu budaya masyarakat suku Sasak yang masih dilaksanakan sampai sekarang. Banjar merupakan suatu bentuk solidaritas masyarakat 
yang diikat oleh suatu kesepakatan aturan sosial dan berwujud bantuan dalam hal tenaga, uang, dan pemikiran. Suku Sasak awalnya bertempat tinggal di Lombok. Akan tetapi, seiring dengan berjalannya waktu, ada sebagian masyarakat yang melakukan transmigrasi ke daerah luar Lombok. Masyarakat Suku Sasak melaksanakan tradisi banjar karena untuk memenuhi kebutuhan pribadi. Banjar terdiri atas beberapa macam, antara lain: banjar subag (banjar sawah), banjar merariq (banjar pernikahan), banjar mate (banjar kematian), dan banjar haji (banjar haji). Jenis banjar tergantung pada acara yang hendak diselenggarakan, seperti yang dikemukakan oleh warga suku Sasak berikut.

"Banyak jenis banjar tergantung begawe nya. Kalau begawe untuk orang naik haji ya banjar haji namanya. Kalau nikahan ya banjar merariq. Kalau banjar subag itu untuk yang P3A itu yang air irigasi di sawah. Kalau banjar subag atau banjar irigasi malah lebih besar lagi. Memakai kerbau dimasak di sawahnya dekat irigasinya," (Nurun, 17-7-2018).

Pelaksanaan banjar memiliki berbagai perbedaan di setiap kampung karena mengikuti kesepakatan masing-masing masyarakat, seperti yang ungkapkan oleh warga suku Sasak berikut.

"Pelaksanaan banjar tergantung aturan tiap kampung. Asli di Kakong sama di Sembaru beda aturannya. Misalnya kalau di Kampung Kakong pemberitahuan akan ada begawe lewat speaker masjid aja cukup. Tapi kalau di Sembaru tidak semua orang ikut membantu dalam begawe, mereka harus diundang satu per satu oleh yang akan punya gawe," (Anep, 19-7-2018)

Kampung Kakong terletak di desa Bentek, kecamatan Gangga, Kabupaten Lombok Utara, Provinsi Nusa Tenggara Barat. Masyarakat suku Sasak di Kakong masih melaksanakan tradisi banjar hingga sekarang. Masyarakat melakukan koordinasi antar anggota banjar dengan cara melakukan pertemuan atau rapat. Rapat diadakan secara rutin setiap satu bulan sekali atau setiap akan dilaksanakan begawe. Perkumpulan banjar memiliki uang kas yang didapat dari iuran anggota setiap satu bulan sekali sebesar dua ribu rupiah. Terdapat ketua, sekretaris dan bendahara yang menjadi pengurus harian perkumpulan Banjar. Pengurus harian ditunjuk oleh masyarakat seperti yang dikatakan oleh warga suku Sasak, "Banjar itu ada ketua, sekretaris, bendahara. Itu semua ditunjuk oleh masyarakat. Biasanya orang-orang itu yang pinter ngatur dan cekatan" (Nurun, 19-07-2018).

Hampir semua orang di Kampung Kakong tergabung dalam perkumpulan banjar karena hanya pengantin baru dan yang belum menikah yang tidak tergabung. 
Keanggotaan banjar dilakukan secara sukarela karena berdasarkan pada asas solidaritas dan kebutuhan pribadi. Anggota banjar tidak hanya berasal dari masyarakat suku Sasak, tetapi semua masyarakat yang tinggal di kampung Kakong diperbolehkan bergabung, seperti yang diutarakan oleh warga suku Sasak. "Semua boleh gabung meski bukan suku Sasak yang penting daftar dulu ke RT karena berkaitan dengan kependudukan. Kalau sudah terdaftar maka otomatis harus mengikuti aturan sosial yang ada di sini" (Dwi, 19-07-2018).

Fungsi perkumpulan Banjar akan terasa pada saat prosesi begawe, misalnya dalam rangka resepsi pernikahan. Orang Sasak biasa menyebutnya sebagai banjar merariq. Pemberitahuan terkait akan adanya prosesi begawe diumumkan melalui speaker masjid atau mushola bahwa pada hari tertentu, tanggal tertentu akan ada begawe di rumah seseorang. Semua anggota Banjar secara silih berganti akan datang untuk membantu. Setiap orang yang datang khususnya ibu-ibu membawa sebuah mangkuk yang ditutup taplak meja dan diisi dengan berbagai barang, misalnya beras, pisang, snack bungkusan, mie instan, dan lain sebagainya. Bagi orang yang belum menikah diperbolehkan untuk menghadiri prosesi begawe dengan membawa kado atau amplop yang berisikan uang. Barang-barang yang dibawa para anggota Banjar yang datang diberikan kepada orang yang punya begawe. Hasil dari pengumpulan barang-barang bawaan setiap orang yang datang nantinya akan dikembalikan kepada orang-orang tersebut juga. Mangkuk yang awalnya digunakan untuk membawa barang bawaan pada saat datang, nantinya akan diisi dengan berkat pada saat pulang atau acara begawe selesai. Berkat berupa kue-kue jajanan, beras, minyak, mie instan, dan barang-barang lain yang dibawa oleh anggota Banjar. Akan tetapi, pembagian berkat dilakukan secara adil. Pembagian berkat tidak dipukul rata karena harus memperhatikan peran dan tanggung jawab setiap anggota banjar selama prosesi begawe berlangsung.

Prosesi begawe memakan banyak waktu karena memerlukan persiapan yang matang. Persiapan begawe dimulai dari menampi (membersihkan beras untuk keperluan begawe), mengumpulkan kayu untuk memasak selama begawe, mendirikan tenda untuk acara begawe, hingga menerima kedatangan kedua mempelai setelah acara nyongkolan. Nyongkolan adalah salah satu kegiatan dari serangkaian prosesi merariq di mana kedua mempelai diarak dari rumah mempelai laki-laki menuju ke rumah mempelai perempuan. Begawe diselenggarakan kurang lebih dalam waktu dua hari tanpa menghitung acara persiapan. Selama berlangsungnya acara tersebut, sebagian besar 
warga tidak memasak di rumah karena sudah dapat makan di rumah yang punya begawe. Pada umumnya warga makan tiga kali selama begawe, yaitu dua kali pada saat satu hari sebelum nyongkolan dan sekali pada hari nyongkolan.

Tuan rumah yang punya acara sangat terbantu oleh semua anggota Banjar yang hadir dan membantu selama prosesi begawe. Keperluan selama begawe diatur oleh para anggota yang hadir termasuk keperluan hidangan. Orang yang mengatur keperluan hidangan tersebut biasa dipanggil dengan sebutan Ran. Terdapat beberapa ran, antara lain ran sayur (orang yang mengatur kebutuhan sayur mayur), ran nasi (orang yang mengatur keperluan beras dan nasi), dan ran daging (orang yang mengatur kebutuhan daging). Orang-orang tersebut juga termasuk ke dalam anggota banjar. Pemilihan anggota Banjar yang akan dijadikan sebagai ran tidak melalui mekanisme tertentu tetapi pengalaman yang menentukan. Kinerja orang-orang yang menjadi ran telah terbukti sehingga tanpa melalui penunjukan dan secara otomatis pada setiap ada begawe maka orang yang sama yang menjadi ran. Apabila orang yang terbiasa menjadi ran berhalangan maka akan digantikan dengan cara memilih ran melalui musyawarah. Meskipun seluruh keperluan selama begawe diatur oleh anggota banjar yang hadir, tuan rumah yang punya begawe tetap diajak koordinasi.

\section{Pembangunan Budaya Anti Korupsi melalui Tradisi Banjar}

Perkumpulan Banjar yang sudah turun temurun dilaksanakan masyarakat di Kampung Kakong secara tidak langsung dapat menjadi upaya membangun budaya anti korupsi. Pelaksanaan banjar khususnya banjar merariq di Kampung Kakong penuh dengan nilai-nilai antikorupsi. Pertama, nilai kejujuran terlihat pada saat anggota Banjar dipercaya tuan rumah yang punya begawe untuk mengatur segala keperluan selama prosesi begawe. Bura dan Puspito (Fauziyah, 2015) mengemukakan bahwa kejujuran adalah perilaku yang didasarkan pada upaya menjadikan dirinya sebagai orang yang selalu dapat dipercaya dalam perkataan, tindakan dan pekerjaan. Orang-orang tersebut memilih untuk menjalankan amanah sehingga para anggota banjar dapat menjalin kepercayan satu sama lain, meskipun orang-orang tersebut memiliki banyak kesempatan untuk berbuat nakal, misalnya melebih-lebihkan kebutuhan pasokan beras untuk kepentingannya sendiri atau kepentingan sekelompok orang. 
Uslaner (Angraeni, 2016) mengatakan bahwa ada keterkaitan antara korupsi dan budaya. Budaya yang didominasi dengan nuansa "mis-trust" memiliki kaitan yang erat dengan tingkat korupsi yang tinggi. Sedangkan, budaya yang didominasi dengan nuansa "trust" berkorelasi positif dengan tingkat korupsi yang rendah. Oleh karena itu, nuansa "trust" dalam budaya masyarakat perlu dibangun karena menjadi salah satu upaya pencegahan korupsi.

Kedua, nilai kedisiplinan terlihat pada saat persiapan dan pelaksanaan begawe. Setelah diumumkan bahwa akan diadakan begawe merariq di rumah salah satu anggota banjar, maka anggota banjar yang lain akan ikut serta dalam mempersiapkan segala keperluan untuk begawe hingga pelaksanaan begawe. Misalnya pada saat persiapan, beberapa hari sebelum begawe, anggota Banjar membawa beberapa ikat kayu bakar untuk keperluan begawe. Hal tersebut sudah menjadi kewajiban bagi semua anggota banjar. Meskipun tidak ada aturan tertulis, hal tersebut sudah menjadi kebiasaan yang dilakukan sebelum begawe. Apabila terdapat salah seorang anggota yang tidak membawa kayu bakar maka akan dikenai sanksi sosial yaitu akan menjadi omongan semua orang.

Ketiga, nilai tanggung jawab terlihat selama prosesi begawe. Nilai tanggung jawab tersirat pada perilaku para anggota banjar yang diberikan amanah untuk membantu mengatur segala keperluan selama begawe. Menurut Bura dan Puspito (Fauziyah, 2015), tanggung jawab merupakan perilaku dan sikap yang melaksanakan tugas dan kewajiban yang harus dilakukan terhadap diri sendiri, masyarakat, lingkungan (alam, sosial, dan budaya), negara dan Tuhan. Para anggota Banjar menyelesaikan segala tugas dan amanah secara bertanggung jawab baik secara pribadi maupun secara tim. Misalnya, terdapat kesalahan pada pengaturan jumlah kebutuhan pasokan daging maka yang bertanggung jawab adalah orang yang bertindak sebagai ran daging. Amanah sebagai ran daging merupakan amanah yang diberikan kepada individu sehingga yang bertanggung jawab adalah individu yang bersangkutan. Berbeda halnya dengan tugas yang dikerjakan secara berkelompok, maka tanggung jawab juga diemban secara berkelompok. Misalnya, pada saat pemasangan tenda yang menjadi tugas sekelompok anggota Banjar yang laki-laki, maka apabila terdapat kesalahan pada pemasangannya maka menjadi tanggung jawab sekelompok orang tersebut. Sedangkan tanggung jawab tuan rumah yang punya begawe adalah mengontrol agar prosesi begawe tidak menimbulkan kesalahpahaman di antara para anggota banjar. Oleh karena itu, tuan 
rumah selalu berkoodinasi dengan para anggota Banjar yang sedang menjalankan amanah dan tugas masing-masing.

Keempat, nilai kerja keras terlihat jelas selama persiapan dan prosesi begawe diselenggarakan. Hampir semua orang anggota banjar di Kampung Kakong datang untuk membantu tuan rumah yang punya begawe. Tidak ada anggota yang datang hanya untuk memakan makanan yang telah dihidangkan tanpa mengerjakan suatu tugas tertentu. Semua orang sibuk dengan tugas masing-masing. Meskipun demikian, tugas dari setiap orang bersifat fleksibel kecuali orang-orang yang mendapat amanah menjadi ran. Misalnya, apabila tenaga untuk menyajikan hidangan masakan sudah dikerjakan oleh seseorang atau sekelompok orang, maka anggota Banjar yang lain dapat membantu mengerjakan tugas yang lain begitu sebaliknya. Khusus tugas yang menjadi tanggung jawab ran maka dari persiapan hingga pelaksanaan begawe dikerjakan orang tersebut sendiri atau dengan bantuan orang lain. Dengan demikian, semua orang bekerja keras. Kerja keras menurut Bura dan Puspito (Fauziyah, 2015), didefinisikan sebagai perilaku yang menunjukkan upaya sungguh-sungguh dalam mengatasi berbagai hambatan, belajar, dan tugas, serta menyelesaikan tiga dengan sebaik-baiknya.

Kelima, nilai kesederhanaan dapat dilihat dari pelaksanaan begawe. Sederhana menurut Bura dan Puspito (Fauziyah, 2015) diartikan sebagai perilaku yang tidak berlebihan, apa adanya, hemat, rendah hati, dan sesuai kebutuhan. Meskipun tenaga dan pemikiran serta sebagian dana dibantu oleh anggota banjar yang datang, pelaksanaan begawe menyesuaikan dengan kemampuan finansial tuan rumah. Misalnya, nyongkolan dilakukan secara sederhana tanpa menyewa kendaraan yang mewah dan fotografer yang handal. Tujuan dari nyongkolan adalah untuk memberitahukan kepada masyarakat bahwa kedua mempelai telah sah menjadi sepasang suami istri. Oleh karena itu, pelaksanaan acara nyongkolan dapat dilakukan secara sederhana agar tujuan utama tercapai.

Keenam, nilai kemandirian dapat dilihat dari sumber dana yang digunakan tuan rumah untuk menyelenggarakan begawe. Meskipun tuan rumah memperoleh barang-barang dan uang para tamu yang datang, kebutuhan untuk memenuhi segala keperluan dalam begawe cukup besar. Semakin banyak para anggota Banjar yang datang maka semakin banyak kebutuhan makanan yang harus dihidangkan sehingga membutuhkan dana yang cukup besar. Dana tersebut diperoleh tuan rumah dari 
sumber yang beragam. Khusus tuan rumah mempelai perempuan memperoleh bantuan dana dari pihak mempelai laki-laki yang berupa uang mahar. Sedangkan tuan rumah mempelai laki-laki memperoleh dana untuk begawe bisa dari hasil tabungan sebelum menikah atau dari dana hasil arisan. Dengan demikian, nilai kemandirian terlihat pada perilaku tuan rumah yang punya begawe.

Ketujuh, nilai keadilan dapat dilihat dari bentuk apresiasi yang diberikan oleh tuan rumah yang punya begawe kepada para anggota Banjar yang datang membantu. Apresiasi diberikan sesuai dengan tugas dan tanggung jawab yang diemban. Meskipun semua apresiasi diberikan dalam bentuk berkat, akan tetapi isinya berbeda. Anggota banjar yang mengemban amanah sebagai ran akan memperoleh isian berkat dengan jumlah barang yang lebih banyak dari pada orang yang sekedar membantu. Selain itu, nilai keadilan juga terlihat pada saat prosesi begawe sedang belangsung dan setelahnya tepatnya melihat dari partisipasi dan keaktifan masing-masing anggota banjar. Misalnya, terdapat salah satu anggota Banjar yang tidak banyak ikut membantu karena malas dalam prosesi begawe di rumah anggota Banjar yang lain, maka hal yang sama akan dilakukan oleh tuan rumah. Apabila kelak di rumah anggota banjar yang malas tersebut diadakan begawe, maka tuan rumah yang sebelumnya punya begawe juga tidak akan banyak membantu. Dengan demikian, nilai keadilan dalam pelaksanaan banjar dilakukan berdasarkan asas proporsional dan berkesinambungan.

Kedelapan, nilai keberanian terlihat pada perilaku masing-masing anggota Banjar baik yang datang membantu maupun tuan rumah yang punya begawe. Keberanian anggota banjar yang datang membantu terlihat pada saat menerima amanah untuk menjalankan sebuah tugas. Misalnya, seorang anggota Banjar berani mengemban amanah sebagai ran beras sehingga berani mengambil resiko untuk bertanggung jawab apabila terdapat kesalahan pada saat menjalankan amanah. Keberanian tuan rumah tampak pada saat memberikan amanah kepada seorang anggota banjar untuk menjalankan tugas tertentu. Tuan rumah berani mengambil resiko apabila orang yang dipercaya tidak sesuai dengan harapan.

Kesembilan, nilai kepedulian terlihat pada komitmen yang dimiliki para anggota Banjar. Kepedulian menurut Boyatzis \& McKee (Prayitno, 2016) adalah wujud dari empati dan perhatian yang mendorong manusia untuk menjalin hubungan dengan orang lain. Semua orang termasuk pendatang dapat menjadi bagian dari anggota Banjar. 
Tidak menutup kemungkinan bahwa proporsi anggota keluarga dari masing-masing anggota Banjar tidak sama. Misalnya, ada anggota Banjar yang memiliki banyak anak dan ada anggota banjar yang memiliki satu anak bahkan belum punya anak karena masih terhitung pengantin baru. Seharusnya hal yang demikian menjadi suatu ketidakadilan bagi anggota Banjar yang memiliki anak sedikit bahkan belum punya anak. Anggota banjar yang memiliki banyak anak maka cenderung akan mengadakan begawe merariq lebih banyak dari pada yang memiliki sedikit anak. Akan tetapi, keanggotaan perkumpulan Banjar tidak dibatasi sehingga semua dapat bergabung. Hal tersebut menandakan bahwa keikutsertaan menjadi anggota Banjar tidak hanya berbasis pada kebutuhan tetapi juga pada kepedulian terhadap sesama.

Pelaksanaan tradisi banjar dalam begawe khususnnya banjar merariq tersebut masih tetap dilaksanakan tanpa membatasi latar belakang kesukuan dari anggota yang hendak bergabung. Anggota masyarakat yang berasal dari suku lain di luar suku Sasak dapat bergabung untuk menjadi anggota Banjar. Selain itu, setiap pelaksanaan begawe, keluarga dari setiap anggota Banjar dapat diajak termasuk anak-anak. Para orang tua anggota banjar maupun sanak saudara memberitahukan tentang tradisi banjar kepada anggota keluarganya termasuk anak-anaknya.

Oleh karena itu, pelaksanaan tradisi Banjar dapat disebut memuat pendidikan anti korupsi meskipun tanpa kurikulum yang tertulis. Angraeni (2016) mengemukakan bahwa pendidikan antokorupsi dapat dipahami sebagai upaya pengembangan segala potensi yang dimiliki masyarakat untuk mewujudkan budaya antikorupsi dalam kehidupan masyarakat, berbangsa, dan bernegara. Potensi yang dimaksud yaitu nilai dan norma yang menjadi pedoman kehidupan sehari-hari. Budaya anti korupsi yang terbangun akan mendorong masyarakat untuk memiliki karakter yang baik. Karakter yang baik meliputi tiga proses psikologis yaitu mengetahui hal yang baik (knowing the good), menginginkan hal yang baik (desiring the good), dan melakukan hal yang baik (doing the good) (Lickona, 2015). Dengan demikian, orang yang berkarakter adalah orang yang memiliki integritas sehingga pikiran, perasaan, dan kehendak serta perilakunya sejalan dan konsisten. Pengenalan dan pembiasaan nilai-nilai anti korupsi dalam tradisi Banjar dapat menjadi budaya anti korupsi di masyarakat. 


\section{Kesimpulan}

Salah satu kearifan lokal di Lombok yaitu tradisi Banjar mengandung nilainilai anti korupsi. Nilai-nilai anti korupsi tersebut, antara lain jujur, disiplin, tanggung jawab, kerja keras, sederhana, mandiri, adil, berani, dan peduli. Nilai-nilai tersebut terlihat pada perilaku para anggota Banjar saat mempersiapkan dan melaksanakan begawe khususnya begawe merariq. Pelaksanaan Banjar telah mendarah daging bagi masyarakat Lombok khususnya Lombok Utara. Pengenalan tentang Banjar kepada para generasi penerus dilakukan baik melalui pembiasaan di masyarakat maupun melalui sebuah wejangan oleh orang tua kepada anak. Dengan demikian, banjar dapat menjadi upaya masyarakat khusus di Lombok untuk membangun budaya anti korupsi.

Berdasarkan hasil temuan dan penelitian, maka penulis memberikan saran terkait penelitian yaitu, (1) Masyarakat Indonesia kaya dengan kearifan lokal yang mengandung nilai-nilai positif termasuk pelaksanaan banjar sehingga harus dilestarikan; (2) Pembudayaan nilai anti korupsi melalui pelaksanaan banjar merupakan sebuah aposteriori karena masyarakat sendiri tidak mengetahui dan menyadari bahwa pelaksanaan banjar mengandung nilai anti korupsi. Oleh karena itu, aposteriori tentang pembudayaan nilai anti korupsi melalui pelaksanaan banjar perlu dirumuskan menjadi apriori dan diajarkan pada pendidikan formal di sekolah maupun di perguruan tinggi. Dengan demikian, akan diperoleh manfaat yang berkelanjutan yaitu tradisi pelaksanaan banjar tetap lestari dan peserta didik dapat menjadi anggota masyarakat yang menginternalisasi nilai-nilai anti korupsi.

Berdasarkan hasil temuan penelitian, maka penulis memiliki beberapa rekomendasi. Pertama, penelitian ini dapat dijadikan referensi bagi pemerintah untuk menyusun kebijakan terkait pendidikan anti korupsi berbasis kearifan lokal. Kedua, penelitian ini dapat digunakan sebagai bahan kajian bagi pihak yang berkaitan, termasuk KPK, untuk menyusun program yang berkaitan dengan pendidikan anti korupsi pada masyarakat berbasis kearifan lokal. Ketiga, Penelitian ini dapat digunakan untuk menambah wawasan bagi pembaca tentang pendidikan anti korupsi berbasis kearifan lokal. 


\section{Ucapan Terima Kasih}

Penulis mengucapkan terima kasih kepada semua pihak yang telah membantu dalam persiapan, pelaksanaan, hingga penulisan makalah ini. Ucapan terima kasih terutama penulis ucapkan kepada para narasumber yang telah bersedia meluangkan waktu untuk membantu proses pengumpulan data penelitian. Tidak lupa penulis sampaikan terima kasih kepada Universita Tidar yang telah mendukung penulis untuk menghasilkan karya baru.

\section{Daftar Rujukan}

\section{Buku}

Angraeni, Sari. (2016). Program Pencegahan Korupsi Berbasis Keluarga. Jakarta: KPK.

Creswell, John. (2015). Riset Pendidika: Perencanaan, Pelaksanaan, dan Evaluasi Riset Kualitatif \& Kuantitatif. Yogyakarta: Pustaka Pelajar.

Lickona, Thomas. (2015). Character Matters Persoalan Karakter Bagaimana Membantu Anak Mengembangkan Penilaian yang Baik, Integritas, dan Kebajikan Penting Lainnya. Diterjemahkan oleh Juma Abdu Wamaungo \& Jean Antunes Rudolf Zien. Jakarta: Bumi Aksara.

\section{Jurnal}

Kristanto, Nurdien Harry. (2015). Tentang Konsep Kebudayaan. Sabda: Jurnal Kajian Kebudayaan, Vol. 10(2), Hlm. 1-11. https:// ejournal.undip.ac.id/index.php/sabda/article/viewFile/13248/1 0033

Nurinten, Dinar, dkk. (2016). Kearifan Lokal Sebagai Media Pendidikan Karakter Antikorupsi pada Anak Usia Dini Melalui Strategi Dongkrak. Jumal Integritas Vol. 2(1), Hlm. 135-154, https://jurnal.kpk.go.id/index.php/integritas/article/download/128/26 $/ \mathrm{s}$

Rahardjo, Mudjia. (2017). Studi Kasus dalam Penelitian Kualitatif: Konsep dan Prosedurnya. https://core.ac.uk/download/pdf/80816930.pdf

Rahmatiani, Lusiana. (2016). Nilai Kearifan Lokal Sunda sebagai Basis Tata Kelola Pemerintahan yang Baik (Good Governance). Civics, Vol. 1(1). Hlm. 81-88. 
http://journal.ubpkarawang.ac.id/index.php/PPKn/article/download/3 $0 / 29$

Rahmatulloh, Johan. (2017). Legalitas Kewenangan Penyelenggara Pendidikan dalam Menarik Pungutan di Satuan Pendidikan Dasar. Integritas, Vol. 3(2). Hlm. 137-156.

https://jurnal.kpk.go.id/index.php/integritas/issue/view/7/Jurnal-

INTEGRITAS-Volume-3-No-2-tahun-2017

Rizal, Moch. Choirul dan M. Lutfi Rizal Farid. (2017). Pitutur Luhur untuk Pemberantasan Korupsi di Indonesia dalam Perspektif Kebijakan Hukum Pidana. Refleksi Hukum Jurnal Ilmu Hukum, Vol. 2(1), Hlm. 33-50. http://ejournal.uksw.edu/refleksihukum/article/view/1250/848

Rusdi, Mughny Ilman Wali dan Susanti Prasetyaningrum. (2015). Nilai Budaya Siri'na Pacce dan Perilaku Korupsi. Jurnal Indigenous, Vol. 13(2), Hlm. 68-86. http://journals.ums.ac.id/index.php/indigenous/article/view/2619/172 2

Saifulloh, Putra Perdana Ahmad. (2017). Peran Perguruan Tinggi dalam Menumbuhkan Budaya Anti Korupsi di Indonesia. Jurnal Hukum \& Pembangunan Tabun ke-47, no. 4. Hlm. 459-476. http://jhp.ui.ac.id/index.php/home/article/download/1591/1468

Santoso, Listiyono dan Dewi Meyrasyawati. (2015). Model Strategi Kebudayaan dalam Pemberantasan Korupsi di Indonesia. Jurnal Review Politik, Vol. 05(01), Hlm. $22-45$. http://jurnalpolitik.uinsby.ac.id/index.php/jrp/article/view/58/58

Setiyono, Budi. (2017). Memahami Korupsi di Daerah Pasca Desentralisasi: Belajar dari Empat Studi Kasus. Politika, Vol. 8 (1), Hlm. 27-62. https://ejournal.undip.ac.id/index.php/politika/article/viewFile/16354 $/ 11974$

\section{Artikel Daring}

Alhamid, Thalha dan Budur Anufia. (2019). Resume: Instrumen Pengumpulan Data. Diakses $18 \quad$ Maret 2018, pada https://osf.io/s3kr6/download/?format=pdf 
Budiawati, Arie Dwi. (2018). Daftar Terbaru Negara Terkorup, Indonesia Rangking Berapa?. Diakses 21 Juli 2018, pada https://www.dream.co.id/unik/daftarterbaru-negara-terkorup-indonesia-ranking-berapa-180223d.html

Fauziyah, Fitri. (2015). Nilai-Nilai Pendidikan Antikorupsi dalam Alqur'an: Kejujuran, Tanggung Jawab dan Kesederhanaan. Diakses 21 Juli 2018, pada http://eprints.ums.ac.id/39791/1/NASKAH\%20PUBLIKASI.pdf

Gabrillin, Abba. (2018). Dalam 2 Tahun, 11 Kepala daerah di Jatim jadi Tersangka Kasus Korupsi. Diakses 15 Maret 2018, pada https://nasional.kompas.com/read/2018/10/10/05283531/dalam-2tahun-11-kepala-daerah-di-jatim-jadi-tersangka-kasus-korupsi?page $=$ all

Hariyanto, Ibnu. (2017). ICW: Dalam 6 Bulan, 226 Kasus Korupsi Rugikan Negara Rp 1,83 T. Diakses 15 Maret 2019, pada http://news.detik.com/berita/d3621894/icw-dalam-6-bulan-226-kasus-korupsi-rugikan-negara-rp-183-t

ICW. (2017). Kasus Korupsi di Provinsi. Diakses 15 Maret 2019, pada https://antikorupsi.org/id/content/kasus-korupsi-di-provinsi

ICW. (2017). Korupsi Dana Desa \& Kepala Daerah 2017. Diakses 15 Maret 2019, pada https://www.antikorupsi.org/id/content/korupsi-dana-desa-kepaladaerah-tahun-2017?width $=1000$ \&height $=700$

Prayitno, Joko Dwi. (2016). Kepedulian Mahasiswa UNNES terhadap Program Konservasi Universitas Negeri Semarang. Diakses 15 Maret 2019, pada https://lib.unnes.ac.id/27325/1/3201412052.pdf

Rahmawati, Fitria. (2017). Sepanjang 2017, Tim Saber Pungli Tangkap 2426 Tersangka. Diakses $15 \quad$ Maret 2019, pada https://nasional.tempo.co/read/1029454/sepanjang-2017-tim-saberpungli-tangkap-2-426-tersangka

\section{Undang-Undang dan Peraturan Pemerintah}

Undang-Undang Republik Indonesia Nomor 20 Tahun 2001 Tentang Pemberantasan Tindak Pidana Korupsi

Undang-Undang Republik Indonesia Nomor 31 Tahun 1999 Tentang Pemberantasan Tindak Pidana Korupsi. 


\section{Hasil Wawancara}

Anep, warga Suku Sasak. Data diambil pada tanggal 19 Juli 2018.

Dwi Febriyanti, warga Suku Sasak. Wawancara pada tanggal 19 Juli 2018.

Nurun Hidayati, warga Suku Sasak. Wawancara pada tanggal 17-19 Juli 2018. 